\title{
A note on nutritive value of blend of blood and ground maize cob for broiler chickens
}

\author{
A. Donkoh, S. Otchere, U.O. Asare, E. Okyere-Boakye, R.Y. Tawiah \\ and E.K.D. Nyannor
}

Department of Animal Science, Kwame Nkrumah University of Science and Technology

Kumasi, Ghana

(Received 16 December 2002; revised version 21 March 2003; accepted 15 July 2003)

\begin{abstract}
Blend of blood and ground maize cob (BLOMC) was analysed and compared with wheat bran. Experiment was conducted on 300 14-day-old broiler chickens allocated to 5 dietary treatments, each

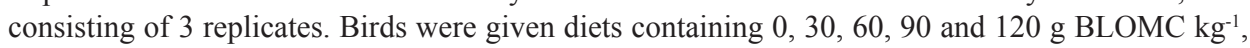
replacing equal amounts of wheat bran.

Growth performance and carcass yield of birds fed diets containing BLOMC did not differ markedly from those on the control diet, except the efficiency of feed utilization, which improved $(\mathrm{r}=$ $0.77 ; \mathrm{P}<0.05)$ with the inclusion of BLOMC in diets. There were neither health-related problems nor mortality due to the addition of BLOMC to the diet. Dietary treatments did not have significant $(\mathrm{P}>0.05)$ impact on organ weights, except the gizzard weight, which was highest $(\mathrm{P}<0.01)$ in birds fed on the diet which contained $120 \mathrm{~g} \mathrm{BLOMC} \mathrm{kg}^{-1}$. Examination of heart, kidney, liver, spleen, lung and pancreas revealed no gross abnormalities from feeding of BLOMC. It was cheaper to produce broilers using BLOMC than using wheat bran.
\end{abstract}

KEY WORDS: blood, maize cob, broiler chickens, growth performance

\section{INTRODUCTION}

In many developing countries with a preponderance of small-scale farms, maize is typically the cereal grain of choice as the main source of energy in commercial broiler diets. In addition, various locally available cereal by-products such as wheat bran, maize bran and rice bran may be used as feed ingredients to 
varying extents. However, at certain times of the year these by-products become scarce and expensive. There are other potential dietary ingredients, generally of agro-industrial origin, that are currently under-exploited for one reason or another. One of these is maize cob, a farm waste in several of the maize producing areas. Results of a pilot study (Donkoh et al., 2003) indicated that ground maize cob could be included in broiler chickens diet up to $75 \mathrm{~g} \mathrm{~kg}^{-1}$ without an adverse effect on performance. Ground maize cob contains low level of protein. As a result, maize cob-containing diets must be supplemented with expensive protein sources like fish meal and soyabean meal or synthetic amino acids. In Ghana, neither soyabean meal nor synthetic amino acids are readily available. Also, the price of fish meal, which is the primary choice for poultry rations, especially among the small-scale operators who account for a greater percentage of the nation's production of chicken meat and eggs, is prohibitive.

Blood from slaughtering of animals blended with maize cob may be used as a feedstuff for poultry. In developing countries a considerable amount of blood is produced in abattoirs. Blood meal is high in protein and rich in lysine, but is susceptible to heat damage during processing, as a result of heat-stimulated reactions between lysine and reducing sugars or other amino acids (Hamm and Searcy, 1976; Waibel et al., 1977; Miller and De-Boer, 1988; Moughan and Donkoh, 1991; Crawshaw, 1994; NRC, 1994). Thus, the use of absorbent such as ground maize cob for the dehydration of raw blood without damaging the nutritive quality would be desirable.

The objective of this study, therefore, was to evaluate a product prepared from blood and ground maize cob as a substitute of wheat bran in diets for broiler chickens.

\section{MATERIAL AND METHODS}

The maize cob used in the study was obtained as a by-product from Asare Farms, Kumasi (Ghana), while the blood was obtained from the Meat Science Unit of the Kwame Nkrumah University of Science and Technology, Kumasi. The blood comprised mainly of that obtained as a result of pig slaughtering but included small amount of that of cattle. The maize cob was ground in a hammer mill, mixed with blood in a proportion of $1: 1(\mathrm{w} / \mathrm{w})$ and solar-dried for 3 days. The resultant product, hereafter referred to as 'BLOMC', was re-ground and stored in sacks until used in formulations.

Chemical composition of blood, maize cob and BLOMC was determined using standard procedures of AOAC (1990), while acid detergent fibre (ADF), neutral detergent fibre (NDF) and hemicellulose content of the maize cob and BLOMC were estimated by Goering and van Soest (1970) method. The nitrogen-corrected 
true metabolizable energy $\left(\mathrm{TME}_{\mathrm{n}}\right)$ content was determined using eight 6-week-old broiler chickens which were force-fed $30 \mathrm{~g}$ of the test ingredient, excreta were collected for $48 \mathrm{~h}$, and endogenous excreta determined by fasting for $24 \mathrm{~h}$ (Sibbald, 1986). The tested ingredient and faecal samples were analysed for gross energy by bomb calorimetry. The $\mathrm{ME}_{\mathrm{n}}$ values for the experimental diets were calculated from values given by the National Research Council (1994) and the determined $\mathrm{TME}_{\mathrm{n}}$ content of BLOMC.

Total surface viable microbial counts were determined in BLOMC by Bainbridge et al. (1996) method, while identification of microbes, which involved the examination of colonial characteristics, morphology, motility, staining and biochemical properties, was carried out using the guidelines of the International Commission on Microbiological Specifications for Food (1978).

Three hundred 14-day-old commercial broiler chickens (Afabro strain) averaging $0.22 \mathrm{~kg}$ body weight were placed in deep litter pens and randomly allocated in equal numbers to five dietary treatments containing 0, 30, 60, 90 and $120 \mathrm{~g}$ BLOMC kg-1 in substitution of wheat bran (Table 1). The diets were isoenergetic and isoprotein. Each treatment had three replicates each consisting of 20 birds. Feed and water were supplied ad libitum. The experiment lasted 5 weeks.

TABLE 1

Composition and nutrient content of experimental diets, $\mathrm{g} \mathrm{kg}^{-1} \mathrm{DM}$ except ME

\begin{tabular}{|c|c|c|c|c|c|}
\hline \multirow{2}{*}{ Ingredient } & \multicolumn{5}{|c|}{ Level of blend of blood and maize cob, $\mathrm{g} \mathrm{kg}^{-1}$} \\
\hline & 0 & 30 & 60 & 90 & 120 \\
\hline Maize & 580 & 580 & 580 & 580 & 580 \\
\hline Fish meal & 190 & 190 & 190 & 190 & 190 \\
\hline Soyabean meal & 80 & 80 & 80 & 80 & 80 \\
\hline Wheat bran & 120 & 90 & 60 & 30 & 0 \\
\hline BLOMC & 0 & 30 & 60 & 90 & 120 \\
\hline Oyster shell & 20 & 20 & 20 & 20 & 20 \\
\hline Vitamin/mineral premix ${ }^{a}$ & 5 & 5 & 5 & 5 & 5 \\
\hline $\mathrm{NaCl}$ & 5 & 5 & 5 & 5 & 5 \\
\hline \multicolumn{6}{|l|}{ Chemical analysis, $\mathrm{g} \mathrm{kg}^{-1}$} \\
\hline crude protein & 225.7 & 225.1 & 224.5 & 223.8 & 223.2 \\
\hline crude fibre & 32.9 & 37.1 & 41.4 & 45.6 & 50.5 \\
\hline crude fat & 49.0 & 48.1 & 47.3 & 46.4 & 45.5 \\
\hline $\mathrm{ME}, \mathrm{MJ} \mathrm{kg}^{-1 \mathrm{~b}}$ & 11.58 & 11.57 & 11.56 & 11.55 & 11.54 \\
\hline \multicolumn{6}{|c|}{$\begin{array}{l}\text { a vitamin-mineral premix supplied, } \mathrm{kg}^{-1} \text { diet: vit. A, } 7500 \mathrm{IU} \text {; vit. } \mathrm{D}_{3}, 2200 \mathrm{IU} \text {; vit. E, } 9.5 \mathrm{IU} \text {; vit. K } \\
1.7 \mathrm{mg} \text {; riboflavin, } 2.5 \mathrm{mg} \text {; cobalamin, } 0.05 \mathrm{mg} \text {; pantothenic acid, } 6 \mathrm{mg} \text {; niacin, } 20 \mathrm{mg} \text {; cholin } \\
240 \mathrm{mg} \text {; folic acid, } 0.5 \mathrm{mg} \text {; Mg, } 2.3 \mathrm{mg} \text {; Fe, } 45 \mathrm{mg} \text {; Cu, } 5.5 \mathrm{mg} \text {; Mn, } 55 \mathrm{mg} \text {; Zn, } 50 \mathrm{mg} \text {; Zn, } 5 \\
\text { mg; I, } 0.8 \mathrm{mg} \text {; Co, } 0.2 \mathrm{mg}\end{array}$} \\
\hline
\end{tabular}


Birds were weighed, feed intake and feed conversion efficiency were calculated at weekly intervals and at the end of the experiment. Mortalities were recorded as they occurred. After the last weighing, two birds per treatment replicate were randomly selected. The birds were starved of feed for $18 \mathrm{~h}$, weighed, killed by cutting the jugular vein, and allowed to bleed for $5 \mathrm{~min}$. Feathers were then removed following a hot water scald. Carcass was weighed and eviscerated and the weights of the gizzard, gastro-intestinal tract and liver were recorded. Carcass yield was calculated from eviscerated weight and liveweight. In addition, the economics of production, defined as income over the costs of production at the time of the experiment, was assessed.

The dietary treatment effects for all the traits measured were assessed for significant differences using analysis of variance. Linear correlation analyses were made using the method of Steel et al. (1997). The computations were performed using the general linear models procedure of SAS (1987).

\section{RESULTS AND DISCUSSION}

The chemical compositions of blood, maize cob and BLOMC, and wheat bran are shown in Table 2. The values obtained for BLOMC were intermediate between those of blood and raw maize cob. In comparison with wheat bran, BLOMC contained less crude protein, ether extract, ash and energy but had more fibre.

TABLE 2

Chemical composition of blood, maize cob, blend of blood and maize cob and wheat bran ${ }^{\mathrm{a}}, \mathrm{g} \mathrm{kg}^{-1} \mathrm{DM}$

\begin{tabular}{lcccc}
\hline Component & Blood & Maize cob & BLOMC & Wheat bran \\
\hline Dry matter & 903.0 & 896.0 & 900.0 & 894.7 \\
Crude protein & 825.3 & 25.0 & 136.0 & 155.6 \\
Ether extract & 14.9 & 4.0 & 10.4 & 42.6 \\
Crude fibre & 35.1 & 347.0 & 251.4 & 97.9 \\
Ash & 20.6 & 24.0 & 18.5 & 50.3 \\
Nitrogen-free extractives & 7.1 & 496.0 & 483.7 & 547.6 \\
Neutral detergent fibre & - & 687.0 & 569.0 & 500.6 \\
Acid detergent fibre & - & 480.0 & 343.0 & 160.8 \\
Hemicellulose & - & 207.0 & 226.0 & 339.8 \\
Metabolizable energy, MJ kg-1 & 13.08 & 4.82 & 5.15 & 5.39 \\
\hline
\end{tabular}

a each value is the mean of three samples

Staphylococcus aureus and Staphylococcus albus were the only microflora isolated from the blend of blood and ground maize cob used in this study. The samples were, however, free from pathogenic bacteria such as, faecal coliform bacteria and Salmonella. 
Data relating to the influence of dietary BLOMC on growth performance and organ weights of broiler chickens are given in Table 3. Average feed consumption and body weight gain varied between diets, but were not statistically different. A significant $(\mathrm{P}<0.05)$ improvement in feed conversion efficiency was obtained as a result of substitution of wheat bran with BLOMC. The improvements in broiler performance resulting from the feeding of dietary BLOMC may be attributed to the improved nutritive quality of those diets as a result of mixing maize cob with blood, an ingredient which is reported to be rich in lysine, the most critical amino acid under practical conditions of feed formulation (Crawshaw, 1997; Donkoh et al., 1999).

TABLE 3

Effects of dietary treatments on growth performance and organ weights of broiler chickens

\begin{tabular}{lcccccccc}
\hline & \multicolumn{7}{c}{ Level of blend of blood and maize cob, $\mathrm{g} \mathrm{kg}^{-1}$} \\
\cline { 2 - 9 } Response criteria & 0 & 30 & 60 & 90 & 120 & $\begin{array}{c}\text { Pooled } \\
\text { SEM }\end{array}$ & $\mathrm{r}$ & $\mathrm{Y}^{1}=$ \\
\hline Feed intake, kg & 3.09 & 3.39 & 3.07 & 3.12 & 2.92 & 0.08 & -0.57 & - \\
Body weight gain, kg & 1.50 & 1.61 & 1.62 & 1.56 & 1.58 & 0.04 & 0.41 & - \\
Feed conversion ratio, & 2.06 & 2.11 & 1.90 & 2.00 & 1.85 & 0.06 & $-0.77^{*}$ & $2.09-0.0017 \mathrm{X}$ \\
$\quad$ kg feed/kg gain & & & & & & & & - \\
Mortality, \% & 8.33 & 5.00 & 5.00 & 5.00 & 0 & - & - & - \\
& & & & & & & & - \\
Weight of, \% LBW & & & & & & & & - \\
$\quad$ carcass & 70.7 & 71.1 & 71.1 & 70.9 & 71.0 & 0.08 & 0.38 & - \\
$\quad$ gastro-intestinal tract & 11.0 & 12.4 & 11.9 & 12.1 & 11.6 & 0.21 & 0.27 & - \\
$\quad$ liver & 2.10 & 1.98 & 2.20 & 2.30 & 2.00 & 0.05 & 0.14 & - \\
$\quad$ gizzard & 2.12 & 2.48 & 2.46 & 2.81 & 3.04 & 0.14 & $0.97^{* *}$ & $2.15+0.0072 \mathrm{X}$ \\
Cost kg-1 feed (US\$) & 0.24 & 0.23 & 0.22 & 0.21 & 0.20 & - & - & - \\
Profit/bird (US\$) & 0.51 & 0.52 & 0.58 & 0.58 & 0.63 & - & - & - \\
\hline
\end{tabular}

$\mathrm{r}$ - correlation coefficient

${ }^{* *} \mathrm{P}<0.01 ;{ }^{*} \mathrm{P}<0.05$

Post-mortem autopsies indicated that mortalities recorded in the present study were not due to the inclusion of BLOMC in broiler diets. The highest mortality was recorded among birds fed on the control diet devoid of BLOMC, while no death was recorded among birds fed on the diet that contained $120 \mathrm{~g} \mathrm{BLOMC} \mathrm{kg}^{-1}$.

BLOMC had no influence on the carcass yield and weight of the internal organs studied, except the gizzard, which increased with increasing dietary level of the BLOMC. This may be attributed to the increasing fibre content as the level of BLOMC in the diets increased. High fibre content of a diet is known to cause thickening and enlargement of the gizzard (Kondra et al., 1974; Deaton et al., 
1979). Necroscopy examination, performed on birds at the end of the study, revealed no gross abnormalities in the major internal organs (heart, kidney, liver, lungs, spleen and pancreas).

It was more economical to use BLOMC in broiler diets and reduce wheat bran use. The cost per kg of feed decreased as dietary BLOMC level was increased. Feed cost was reduced by about US $\$ 40.00$ per tonne when the highest amount of BLOMC was incorporated in broiler diets. This was primarily due to the reduction in wheat bran use; which price was almost two times the price of BLOMC at the time of the study. Profit per bird was increased as BLOMC levels in diet were increased. The highest profit was obtained with birds on $120 \mathrm{~g} \mathrm{BLOMC} \mathrm{kg}^{-1}$ diet. Feed accounts for up to $80 \%$ of the costs in production of poultry in Ghana (Inkumsah, 1971). It is essential therefore that the dietary BLOMC level that will optimize profit be used in feed formulation.

This study shows that a blend of blood and ground maize can replace wheat bran in broiler chicken diet without sacrificing performance, and may reduce feed and production costs.

\section{REFERENCES}

AOAC, 1990. Official Methods of Analysis, Association of Official Analytical Chemists. 15th Edition. Arlington, VA

Bainbridge Z., Tomlins K., Wellings K., Westby A., 1996. Methods for Assessing Quality Characteristics of Non-Grains Starch Staples, Part 3. Laboratory Methods. Natural Resources Institute, Chatham (UK)

Crawshaw R., 1994. Blood Meal: a Review of its Nutritional Qualities for Pigs, Poultry and Ruminant Animals. National Renderers Association Technical Review (UK), 594, p.7

Deaton J.W., McNaughton J.C., Burdick D., 1979. High-fibre sunflower meal as a replacement for soyabean meal in layer diets. Brit. Poultry Sci. 20, 159-162

Donkoh A., Atuahene C.C., Anang D.M., Ofori S.K., 1999. Chemical composition of solar-dried blood meal and its effect on performance of broiler chickens. Anim. Feed Sci. Tech. 81, 299-307

Donkoh A., Nyannor E.K.D., Asafu-Adjaye A., Duah J., 2003. Ground maize cob as a dietary ingredient for broiler chickens in the tropics. J. Anim. Feed Sci. 12, 153-161

Goering H.K., van Soest P.J., 1970. Forage Fiber Analysis (Apparatus, Reagents, Procedures and Some Applications). Agriculture Handbook No. 379. Agriculture Research Service, United States Department of Agriculture. Washington, DC

Hamm D., Searcy G.K., 1976. Some factors which affect the availability of lysine in blood meals. Poultry Sci. 55, 582-587

ICSMF (International Commission on Microbiological Specifications for Food), 1978. Micro-organisms in Foods 1. Their Significance and Methods of Enumeration. 2nd Edition. University of Toronto Press, Toronto (Canada)

Inkumsah J.C.E., 1971. The percentage of feed in relation to total cost of production of poultry. B.Sc. Thesis, University of Science and Technology, Kumasi (Ghana)

Kondra P.A., Sell J.L., Guenter W., 1974. Response of meat and egg-type chickens to a high fibre diet. Can. J. Anim. Sci. 54, 651-658 
Miller E.L., De Boer F., 1988. By-products of animal origin. Livest. Prod. Sci. 19, 159-196

Moughan P.J., Donkoh A., 1991. Amino acid digestibility in non-ruminants - a review. In: D.J. Farrell (Editor). Recent Advances in Animal Nutrition in Australia. University of New England, Armidale (Australia), pp. 172-184

National Research Council, 1994. Nutrient Requirements of Domestic Animals. Nutrient Requirements of Poultry. 9th revised Edition. National Academy Press, Washington, DC

Sibbald I.R., 1986. The TME System of Feed Evaluation: Methodology, Feed Composition Data and Bibliography. Animal Research Center Contribution 85-19, ON (Canada)

Statistical Analysis Systems Institute Inc., 1987. Procedures Guide for Personal Computers. Version 6 Edition. SAS Institute, Cary, NC

Steel R.G.D., Torrie J.H., Dickey D.A., 1997. Principles and Procedures of Statistics. A Biometrical Approach. 3rd Edition. McGraw-Hill, New York

Waibel P.E., Cuperlovic M., Hurrell R.F., Carpenter K.J., 1977. Processing damage to lysine and other amino acids in the manufacture of blood meal. J. Agr. Food Chem. 25, 171-175

\section{STRESZCZENIE}

Wartość pokarmowa mieszanki krwi i mielonych osadek kukurydzianych w żywieniu kurcząt brojlerów

Oznaczono skład i wartość pokarmową mieszanki krwi i osadek kukurydzianych (BLOMC), porównując ją z wartością otrąb pszennych. Doświadczenie przeprowadzono na 300 14-to dniowych kurczętach brojlerach, podzielonych na 5 grup, każda po 3 powtórzenia. Kurczęta otrzymywały diety zawierające 0, 30, 60, 90 i 120 g BLOMC kg-1 , którymi zastępowano taką samą ilość otrąb pszennych.

Wyniki produkcyjne oraz wydajność tuszek ptaków otrzymujących różną ilość BLOMC nie różniły się znacząco od danych dla grupy kontrolnej, z wyjątkiem wykorzystania paszy, które poprawiło się $(\mathrm{r}=0,77 ; \mathrm{P}<0,05)$ przy włączeniu BLOMC do diet. Nie stwierdzono żadnych problemów zdrowotnych ani upadków kurcząt spowodowanych udziałem BLOMC w diecie, ani istotnego wpływu $(\mathrm{P}>0,05)$ diet doświadczalnych na ciężar narządów wewnętrznych, z wyjątkiem żołądka mięśniowego, który był większy $(\mathrm{P}<0,01)$ u ptaków otrzymujących diety z $120 \mathrm{~g} \mathrm{BLOMC} \mathrm{kg}^{-1}$. Nie wykazano także znaczących nieprawidłowości w rozwoju serca, nerek, wątroby, śledziony, płuc i trzustki u ptaków otrzymujących BLOMC.

Zastosowanie BLOMC zamiast otrąb pszennych w dietach dla broilerów zmniejsza koszty produkcji. 